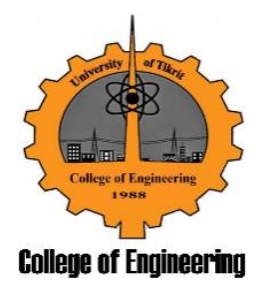

ISSN: 1813-162X (Print) ; 2312-7589 (Online)

Tikrit Journal of Engineering Sciences

available online at: http://www.tj-es.com

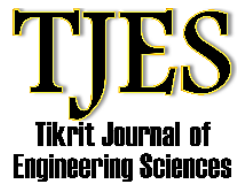

Abbas JK, Al-Luhaibi HM. Influence of Iron Furnaces Slag on Collapsibility and Shear Strength of Gypseous Soil. Tikrit Journal of Engineering Sciences 2020; 27(1): 65-71.

\section{Jawdat K. Abbas}

Hamad M. A. Al-Luhaibi

Civil Department/ Engineering College/Tikrit University/ Tikrit, Iraq

\title{
Influence of Iron Furnaces Slag on Collapsibility and Shear Strength of Gypseous Soil
}

\section{Keywords:}

Collapsible soil Iron furnaces slag

Gypseous soil Shear strength Soaking.

\section{A R T I C L E I N F O}

\section{Article history:}

Received 12 December 2019

Accepted 19 February 2020

Available online 30 March 2020

\section{A B S T R A C T}

Gypseous soil is one of the soils that suffer from problems and suffers from a reduction of shear strength and collapse when exposed to water immersion or water filtration in it.

Many researchers have tried to solve these problems in different ways and by using many

materials as additives to improve the performance and efficiency of this soil. In this : research, the behavior of soil with a high content of gypsum (61.49\%) is examined, using iron slag which is a by-product of the iron making process in melting furnaces, used as 气ั้ an additive in proportions $(2,4,6,8,10 ., 12) \%$, by dry mixing method with soil. Tests are carried out to determine the effect of this substance on the shear strength parameters. The effect of water immersion on soil cohesion (c) is reduced until it reaches (c) in the case of immersion a value very close to the value in the dry state at slag ratio (10) \% This is the optimum ratio of slag to improve the value of (c). Whereas for the value of $(\varnothing)$, with the increase of the slag rate for both wet and dry cases, the value of $(\varnothing)$ increases, where $(\varnothing)$ reaches the highest value at; the slag rate (10)\% for the dry state, and the slag rate $(8) \%$ for the soaked case. Whereas for the collapse potential (Cp), adding the slag reduces the value of the soil collapse potential $(\mathrm{Cp})$, from (10.6) to the soil without additives until (0.95) for the slag rate (12) \%. Then the soil becomes problematic soil.

2019 TJES, College of Engineering, Tikrit University

\section{تأثثر خبث أفران الحديد على قابلية الانهيار وقوة القص في التربة الجبسية}

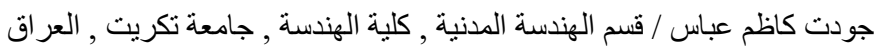
حمد مسلط احمد اللهيبي / قسم الهندسة المدنية , كلية الهندسة , جامعة تكرية بكريت , العراق

التربة الجبسية هي واحدة من الترب التي تعاني من المشاكل وتعاني من انخفاض قوة القص والانهيار عند تعرضها لغندر الماء أو ترشيح الماء خلالها. حاول

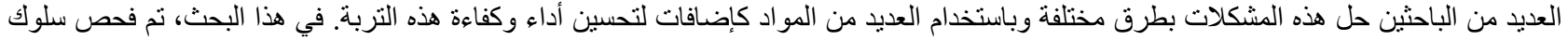

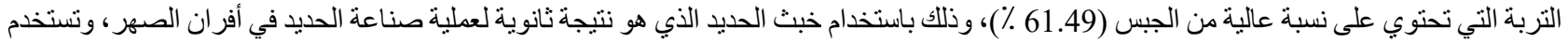

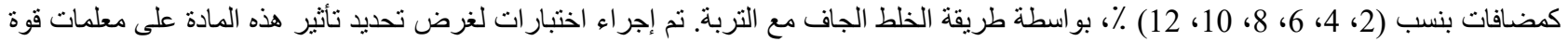

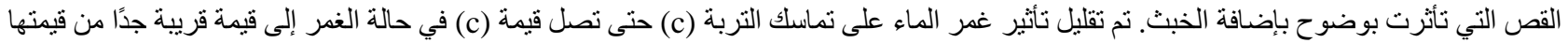

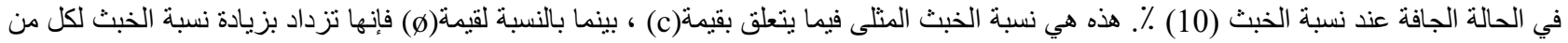

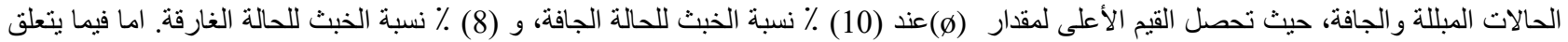

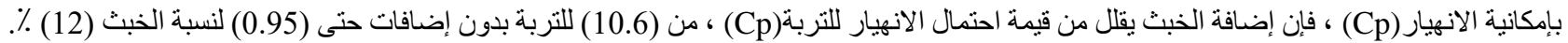
ثم تصبح التربة تربة غير إثكالية. الكلمات الدالة: التربة الانهيارية، خبث افران الحديد، الترب الجبسية، مقاومة القص، الغمر.

* Corresponding Author: E-mail: hamad.m.ahmed42002@st.tu.edu.iq 


\section{INTRODUCTION}

There are many problems encountered by the facilities that are built on gypseous soils, some of them are large, including those that lead to structural failure or impose expensive maintenance of these structures. The most important problems in gypseous soils are the decrease of shear strength when exposed to water or immersion, as well as decline or collapse, which may suddenly happen when the soil is soaked with water or when filtration occurred through the soil [1]. Gypsum is a sulfuric acid salt, its chemical symbol is $\left(\mathrm{CaSO}_{4} \cdot 2 \mathrm{H}_{2} \mathrm{O}\right)$ [2], and it has a hardness value (2.0) on Mohs' scale [3]. Also, it has specific gravity of (2.32). It is white semi-transparent mineral salt [4], [5], and [6]. The solubility of water gypsum is very low (1.8 to $2.4 \mathrm{~g}$ / L) [7]. The terms "gypseous soil" and "gypsiferous soil" are synonymous terms [8]. The gypseous soil covers more than (20) \% of the territory of Iraq [9]. Buringh [10] drew the first map on the distribution of gypseous soil in Iraq as shown in Fig. 1.
Many researchers tried to study the effect of many additives on the behavior of gypseous soils, Ibrahim in 2017 examined the improvement of gypseous soil properties by using the silicone oil to minimize the effect of moisture on these soils [11]. Awn in 2012 tried to improve the gypseous soil with a high gypsum content by reducing the collapsibility by adding Portland cement (resistant- salts) [12]. Aziz in 2011 concentrates on the suitability of fuel oil in improving gypseous soil [13]. Iron furnaces slag (IFS) or blast furnaces slag (BFS) is defined by (ASTM C 989-99, 2003) as "non-metallic product consisting essentially of calcium silicates and other bases, developed in a molten condition simultaneously with pig iron in a blast furnace" [14]. The main oxides in (BFS) are silica, alumina, and magnesia; also, there are some secondary oxides as sulfur oxides and iron oxides [15], [16]. Thus, the aims of this paper is to study and evaluate the effect of "Blast Furnaces Slag (BFS)" on the collapsibility and shear strength parameters of the gypseous soil.

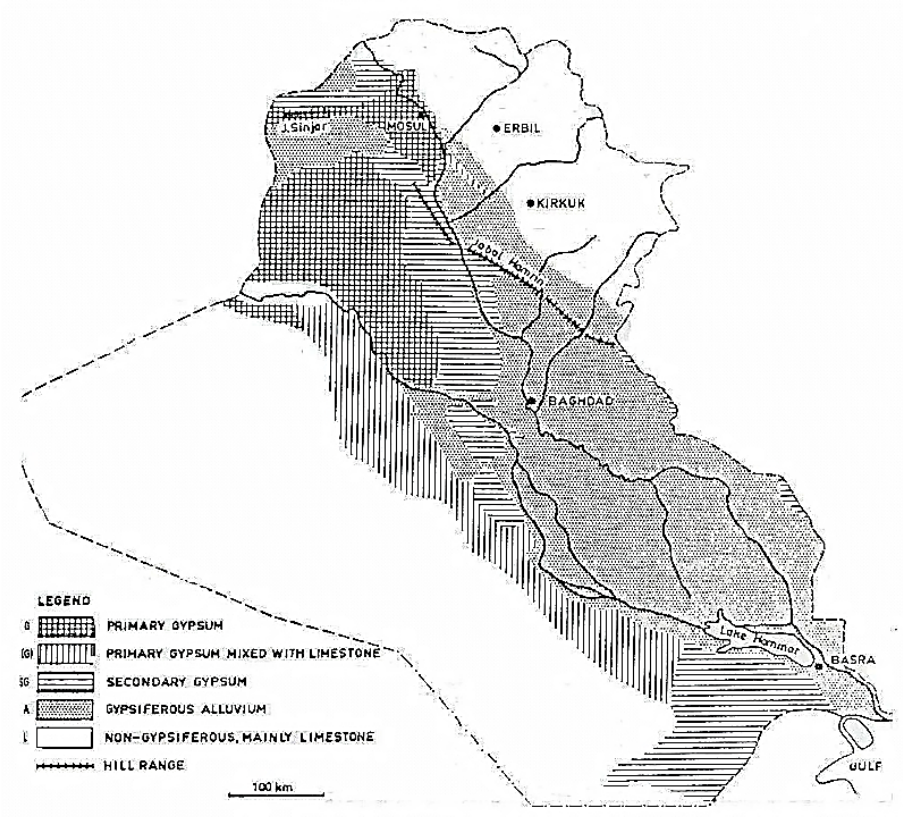

Fig. 1. Distribution of gypseous soil in Iraq (Buringh, 1960)[10]

\section{MATERIALS}

Soil: The soil sample was collected from the site of the University of Tikrit / Salah Al-Deen governorate west-north of Iraq. It is collected after removing the upper soil for a depth of (1.2) m until reaching a natural soil with high gypsum content as obvious by vision, the tests were conducted in the laboratories of Tikrit University / College of Engineering, the properties of the soil are shown in Table 1. Also, an (XRD) examination was conducted in the geological survey laboratories / Ministry of Industry / Baghdad. The results for soil are present in Table 2.

The iron furnaces slag sample was brought from the industrial zone near Zakho north of Iraq, its grinding was done after drying it at the temperature of (40) $\mathrm{C}^{\circ}$. Table 1 presents the physical test (Gs). Table 3 shows the results of the slag oxides test. Whereas the (XRD) scan results for the slag are presented in Table 4. This material, which is an accidental product of the iron industry and stacking it outdoors, which negatively affects the environment, for benefiting from it.

\section{EXPERIMENTAL WORK}

The work included conducting tests on soil specimens, before and after mixing them with the weighted proportions of the proposed slag percentage, for each one of the direct shear tests in both dry and soaked conditions, as well as for the collapsibility test.

\subsection{Direct Shear test}

The direct shear test is carried out according to the standard (ASTM D 3080-98) [17]. The specimens are prepared by mixing the soil with the slag and then left for (24) hours inside a plastic wrap tightly sealed. The specimen shall be placed inside the apparatus box and the test 
begins in the dry state directly. While, in the soaked case, after placing it in the test apparatus box, the specimen is immersed in water for one hour and then testing it [7].

\subsection{Collapsibility test}

The collapsibility is one of the most important characteristics of gypseous soils. There are many methods to determine the soil collapsibility; the most important and the most widely used is "one-dimensional oedometer test", which includes two methods [18]:

1- "Single Oedometer Test, (SOT)", An examination proposed by "Knight" in 1963. In this research this test is adopted, this test is conducted by using the oedometer apparatus. The mixture was put inside the mold of the device with compacting until the sample reached to the density of the field. The determinations must be done and drew the relationships that represent $(\mathrm{e}-\log \sigma \mathrm{v})$. For both dry and immersed parts in the same scheme and note that there is a vertical line on the stress axis when the stress value is (200) $\mathrm{kPa}$, this dropped line represents the collapse index or collapse potential when the amount is divided by the original height of the specimen [19]. Then the collapse potential $\left(C_{P}\right)$ is calculated as the following formula:

$$
\begin{gathered}
\mathrm{CP}=\left(\Delta e \div\left(1+e^{\circ}\right)\right) * 100 \%=\left(\Delta H \div H^{\circ}\right) * \\
100 \% \quad \ldots \ldots \ldots \ldots . . . .(1)
\end{gathered}
$$

Where: $\Delta \mathrm{e}$ : change in voids ratio due to water immersion, $e^{\circ}$ : initial voids ratio, $\Delta \mathrm{H}$ : the change specimen height due to water immersion, $H^{\circ}$ : The original specimen height .

2- "Double Oedometer Test, (DOT)". An examination proposed by [20], they classify the collapsible soil according to the amount of the collapse index, which is named according to the American standard (ASTM) [19], called (Ic), as in Table 5.

Table 1

\begin{tabular}{|c|c|c|c|c|c|}
\hline \multicolumn{6}{|c|}{ Chemical Tests on Soil Sample } \\
\hline No & Test & \multicolumn{2}{|c|}{ Test Name } & Value & Unit \\
\hline 1 & Gypsum content & \multicolumn{2}{|c|}{$\mathrm{SO}_{3}$ content } & 58 & $\%$ \\
\hline 2 & Gypsum content & \multicolumn{2}{|c|}{ Method of Al Mufty and Nashaat (2001) [3] } & 64.98 & $\%$ \\
\hline & \multicolumn{3}{|c|}{ average of gypsum content } & 61.49 & $\%$ \\
\hline \multicolumn{6}{|c|}{ Physical And Mechanical Tests On Soil and Slag Sample } \\
\hline No & Test & Test Name & Specification & Value & Unit \\
\hline 1 & Soil field density $\left(\gamma_{\text {field }}\right)$ & sand - cone test method & ASTM - D $1556-90$ & 1.45 & $\mathrm{~g} / \mathrm{cm}^{3}$ \\
\hline 2 & water content of soil $(\omega)$ & moisture content & ASTM D - $2216-71$ & 5.5 & $\%$ \\
\hline 3 & field dry density of soil $\left(\gamma_{. d}\right)$ & sand - cone method & ASTM - D $1556-90$ & 1.374 & $\mathrm{~g} / \mathrm{cm}^{3}$ \\
\hline 4 & specific gravity (Gs) of soil & Specific gravity of soil & ASTM D - $854-92$ & 2.488 & \\
\hline 5 & \multicolumn{3}{|c|}{ AASHTO Classification of soil } & A-3 & \\
\hline 6 & \multicolumn{3}{|c|}{ USCS Unified classification of soil } & SP & \\
\hline 7 & specific gravity (Gs) of Slag & Specific gravity of slag & ASTM C-127 & 1.835 & \\
\hline
\end{tabular}

Results of tests on soil and slag

Table 2

Mineral in the soil, XRD test results

\begin{tabular}{cccc}
\hline Symbol & G & Q & C \\
\hline $\begin{array}{c}\text { Name of Mineral } \\
\text { Chemical composition }\end{array}$ & Gypsum & Quartz & Calcite \\
$\mathrm{CaSO}_{4}$ & $\mathrm{SiO}_{2}$ & $\mathrm{CaCO}_{3}$ \\
\hline
\end{tabular}

Table 3

Chemical composition of (BFS) sample

\begin{tabular}{cccccccc}
\hline No. & $\mathbf{1}$ & $\mathbf{2}$ & $\mathbf{3}$ & $\mathbf{4}$ & $\mathbf{5}$ & $\mathbf{6}$ & $\mathbf{7}$ \\
\hline Material & $\mathrm{SiO}_{2}$ & $\mathrm{Al}_{2} \mathrm{O}_{3}$ & $\mathrm{Fe}_{2} \mathrm{O}_{3}$ & $\mathrm{CaO}$ & $\mathrm{MgO}$ & $\mathrm{SO}_{3}$ & others \\
Percent On (BFS) \% & 22.16 & 8.37 & 6.11 & 28.96 & 4.15 & 0 & 30.25 \\
\hline
\end{tabular}

Table 4

Mineral in the Slag, XRD test results

\begin{tabular}{ccc}
\hline Symbol & Q & F \\
\hline Name Of Mineral & Quartz & Feldspar \\
Chemical Composition & $\mathrm{SiO}_{2}$ & $\mathrm{CaAl}_{2} \mathrm{Si}_{2} \mathrm{O}_{8}$ \\
\hline
\end{tabular}


Table 5

Collapse index classification according to Jennings and Knight, 1975 [20] and (ASTM D-5333 -03). [19].

\begin{tabular}{cccc}
\hline \multicolumn{2}{c}{ Jennings and Knight, 1975 [21] } & \multicolumn{2}{c}{ ASTM (D5333-2003) standard [20] } \\
\hline $\mathrm{C}_{\mathrm{p}},(\%)$ at $200 \mathrm{kPa}$ & Severity of problem & $\mathrm{I}_{\mathrm{C}},(\%)$ at $200 \mathrm{kPa}$ & Degree of collapse \\
$0-1$ & No problem & 0 & None \\
$1-5$ & Moderate trouble & $0.1-2.0$ & Slight \\
$5-10$ & Trouble & $2.1-6.0$ & Moderate \\
$10-20$ & Severe trouble & $6.1-10.0$ & Moderately severe \\
More than 20 & Very severe trouble & More than 10.0 & Severe
\end{tabular}

\section{RESULTS AND DESCUSSION}

\subsection{Direct shear test}

The test of direct shear was performed using the ratios of the additives mentioned above. The Table 6 confirms the results for dry and immersed cases. Fig. 2 represents the relationship of (cohesion force (c)) with (slag ratio \%) for (dry and soaked conditions). While for the friction angle $(\varnothing)$ Fig. 3 represents the relationship of (internal friction angle) with (slag ratio \%) for (dry condition) and (soaked condition).

As obvious when the slag percentage becomes equal to (10) \%, as shown in Table 6 and Fig. 2, in the soaked state the value of (c) increases significantly until it reaches its highest value in the curve. This value is close to the (c) value at the same ratio of slag in the dry state. From the above, it can be concluded that, the slag ratio (10) $\%$ is the optimum ratio for improving the cohesion value of (c) in sandy soil with high gypsum content. This can be attributed to the fact that when the slag is added to the soil, the fine slag particles will surround some of the particles and grains of the soil and gypsum grains, the quantity of these surrounded particles is proportional to the amount of added slag ratio, (means, the surrounded particles are increased by increasing the amount of added slag), thus reducing the cohesion of gypsum particles and then decreasing the value of cohesion by increasing slag content in the dry state while at the same time giving the role for slag particles as a new bonding material in the soaked state. As for the change in the result of the slag ratio (12\%) compared to the result of the slag ratio $(10 \%)$, it may be due to the difference in the diameters of the soil granules and slag or from the difference in the intensity of mixing between the soil and the slag. While for the value of the internal friction angle $(\varnothing)$ under effecting of soaking, it went down to nearly half of its value in the dry state when the content of slag was (0) \%, the effecting of immersion is decreased as concerned with the $(\varnothing)$ value by increasing the ratio of slag until it reaches the highest value of $(\varnothing)$ when the slag ratio equaled $(8) \%$. From this it can be concluded that the best slag ratio to improve the value of the gypseous soil internal angle of friction is the slag ratio (8) \%. The internal friction is coming from the interlocking phenomenon between the soil particles [21], the cause of the slag effect on the values of friction angle $(\varnothing)$ is that the slag particles are made up of quartz powder and feldspar which has sharp angles, the interlocking property is approximately equal to or similar to that in sandy soils, these slag particles are surrounding the soil granules, and that gives the mixture a new internal friction; this is attributed to the slag features with difficulty of dissolving of slag particles in water. It can be concluded that the values of (c) and $(\varnothing)$ can be improved by using the slag ratio of (10) $\%$ as shown in Table 6, and figures Fig. 2 and Fig. 3.

\subsection{Collapse Potential test}

The double oedometer test method may give an exaggerated potential collapse results to approximately $10 \%$. This is why selecting the single oedometer test may have been more useful in the study [22] and [23]. The tests were conducted to measure the values of collapse potential (Cp). The test was re-carried out for each approved added percentage of slag. The ratios of slag were used in the tests were as follows; $(2,4,6,8$, 10 , and 12) $\%$. The figures which represented the relations of (strain- log app. stress) for each of slag ratio are shown in the figures starting from Fig. 4 to Fig. 10. These data are used to obtain Table 7 which represents the $(\mathrm{Cp})$ values for each percentage of slag which were added to the gypseous soil, and the degree of improvement (ID) obtained from it by calculating it by equation (2). The reader can note the differences in the performance and efficiency of slag proportions in gypsum soils in terms of probable breakdown $(\mathrm{Cp})$, which is shown by making charts for ease of comparison and to determine the direction of the process more clearly, as shown in Fig. 11.

Improving degree $I D=\left((C p x)-\left(C p^{\circ}\right)\right) \div C p^{\circ} \ldots$

Where; $C p x=$ collapse potential for soil with $\mathrm{X} \%$ slag ratio, $C p^{\circ}=$ collapse potential for soil with $0 \%$ slag ratio.

From the results presented above, the potential collapse $(\mathrm{Cp})$ for the gypseous soil amounts to $(0.95)$ when the slag ratio equaled (12) \%, which according to the specifications specified in Table 5, the soil becomes without problems of a collapse. For illustration of the decrease that happened in the potential collapse values of that soil by adding the slag, adding of the slag is leading to be surrounding the soil particles by the slag particles and forming what looks like a cover around the gypsum granules, which prevents the contact between the gypsum with water or reduces it significantly, therefore that the gypsum particles solubility in water was reduced, which leads to reduce the value of $(\mathrm{Cp})$, 
and the increase of added slag ratio. This means increasing the number of slag particles surrounding the gypsum particles, and that decreases the value of the
(Cp) of soil. The general line direction of the process is moving towards a decrease of $(\mathrm{Cp})$ values with an increase in the slag ratio.

\section{Table 6}

Cohesion and friction angle of the soil with slag percentages. (dry and soaked)

\begin{tabular}{lccccc}
\hline $\begin{array}{l}\text { Test } \\
\text { No. }\end{array}$ & Slag ratio & $\mathbf{c ~ k P a}$ & $\boldsymbol{\emptyset}$ degree & \multicolumn{2}{c}{ soaked state } \\
\hline $\mathbf{1}$ & $0 \%$ & 14.786 & 27.434 & 8.5425 & 15.147 \\
$\mathbf{2}$ & $2 \%$ & 12.553 & 27.713 & 8.2265 & 15.088 \\
$\mathbf{3}$ & $4 \%$ & 13.377 & 31.07 & 8.853 & 17.380 \\
$\mathbf{4}$ & $6 \%$ & 11.698 & 31.437 & 6.662 & 20.4756 \\
$\mathbf{5}$ & $8 \%$ & 12.204 & 33.177 & 5.5565 & 21.067 \\
$\mathbf{6}$ & $10 \%$ & 11.276 & 34.165 & 10.807 & 19.305 \\
$\mathbf{7}$ & $12 \%$ & 10.688 & 34.078 & 7.8795 & 20.037 \\
\hline
\end{tabular}

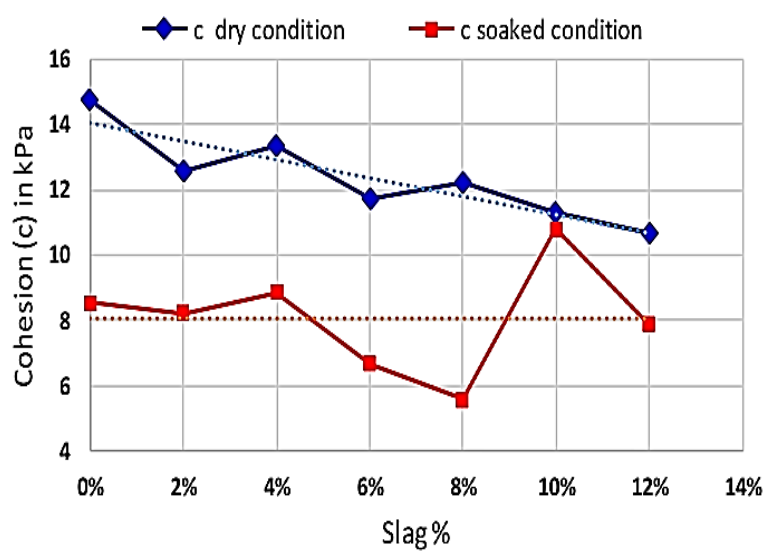

Fig. 2. Relation of c - Slag\%. For dry and soaked condition

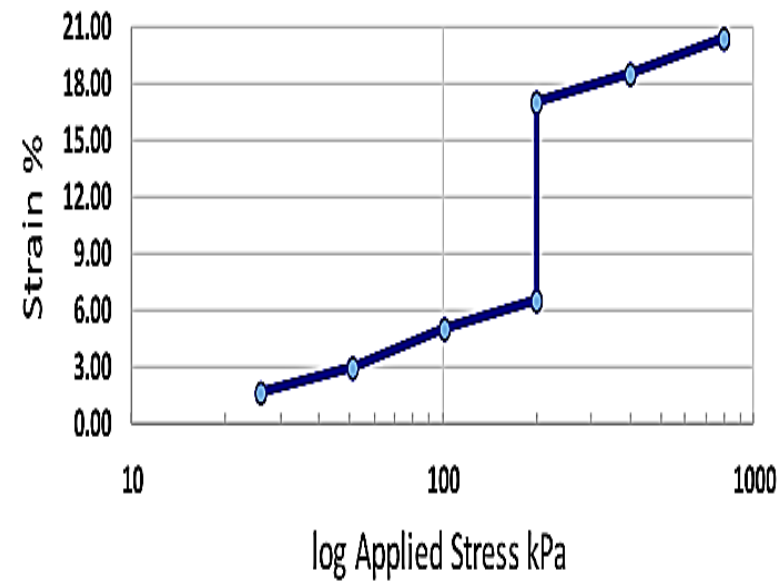

Fig. 4. Strain- log stress relation for the gypseous soil with $0 \%$ slag as additive

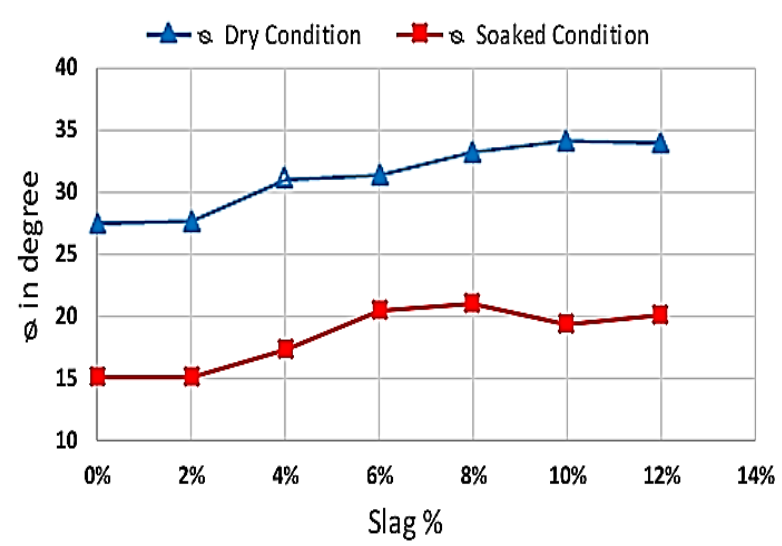

Fig. 3. Relation of $\varnothing-$ Slag\%. For dry and soaked condition

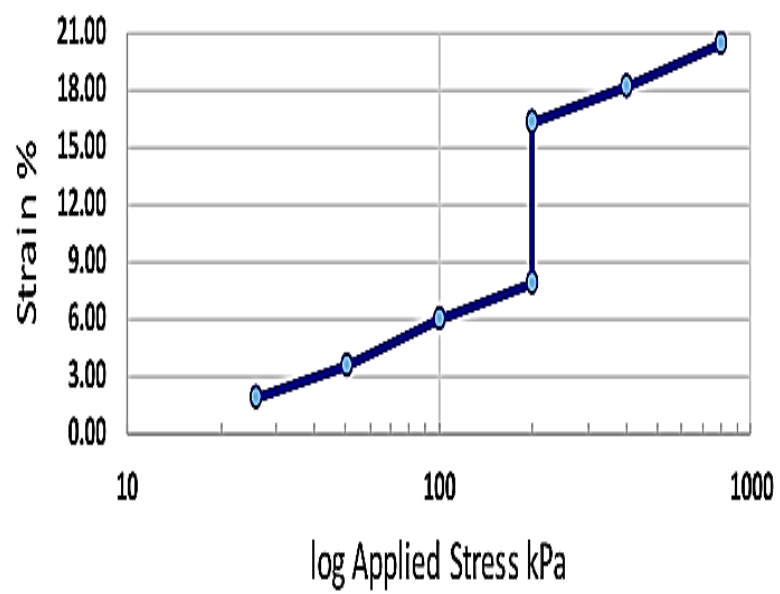

Fig. 5. Strain- log stress relation for the gypseous soil with (2\%) slag as additive 


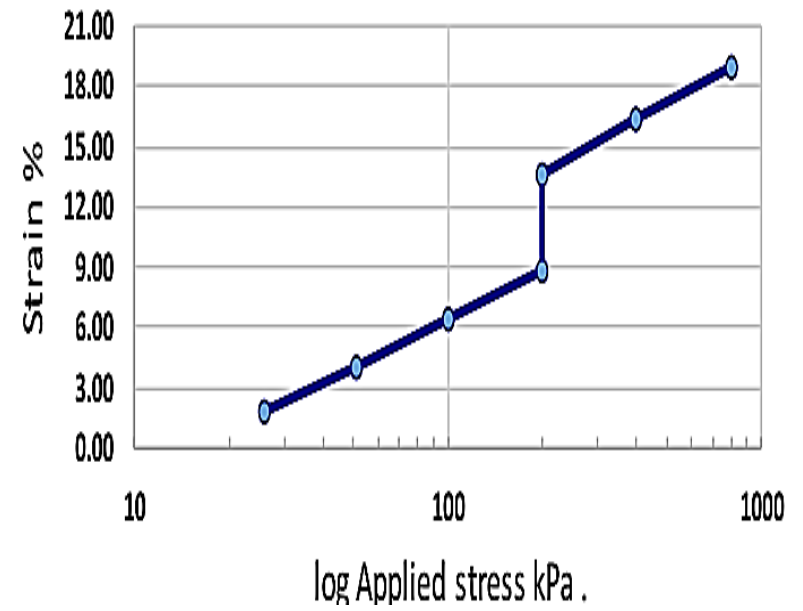

Fig. 7. strain- $\log$ stress relation for the gypseous soil with $(6 \%)$ slag as additive

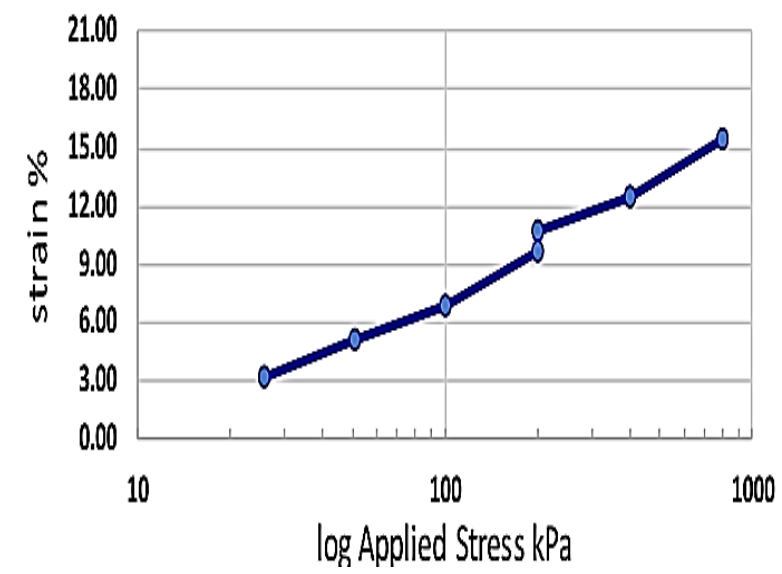

Fig. 9. Strain- log app. Stress relation for the gypseous soil with (10\%) slag as additive

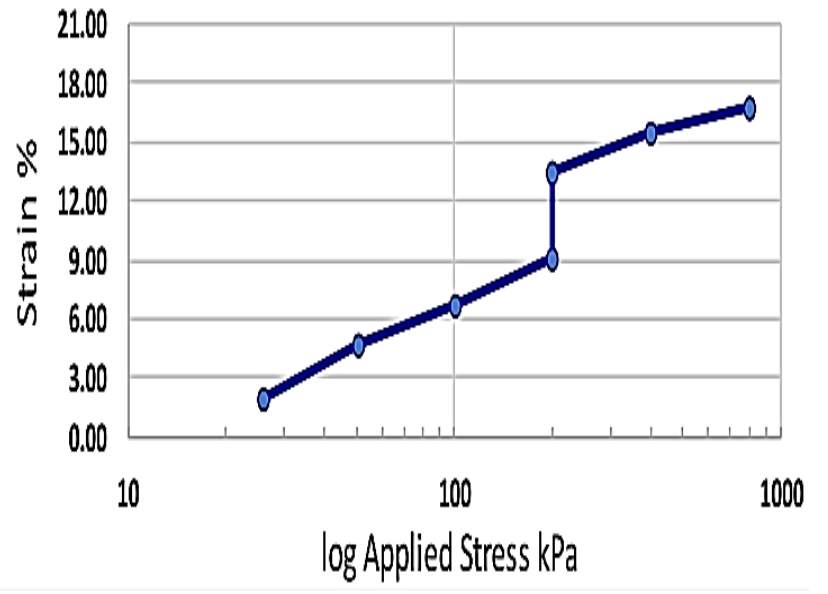

Fig. 8. Strain- $\log$ app. stress relation for the gypseous soil with $(8 \%)$ slag

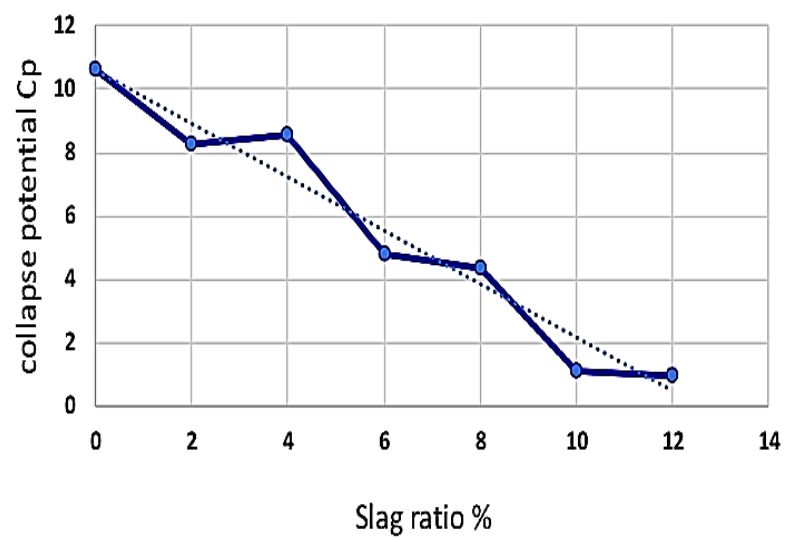

Fig. 10. Strain- log app. Stress relation for the gypseous soil with (12\%) slag as additive

Table 7

Collapse potential and degree of improvement for different slag ratio

\begin{tabular}{cccc}
\hline No. & Slag \% & Collapse Potential (Cp) & Improvement Degree (ID) $\%$ \\
\hline 1 & 0 & 10.6 & 0.000 \\
2 & 2 & 8.25 & 22.170 \\
3 & 4 & 8.55 & 19.340 \\
4 & 6 & 4.8 & 54.717 \\
5 & 8 & 4.35 & 58.962 \\
6 & 10 & 1.1 & 89.623 \\
7 & 12 & 0.95 & 91.038 \\
\hline
\end{tabular}

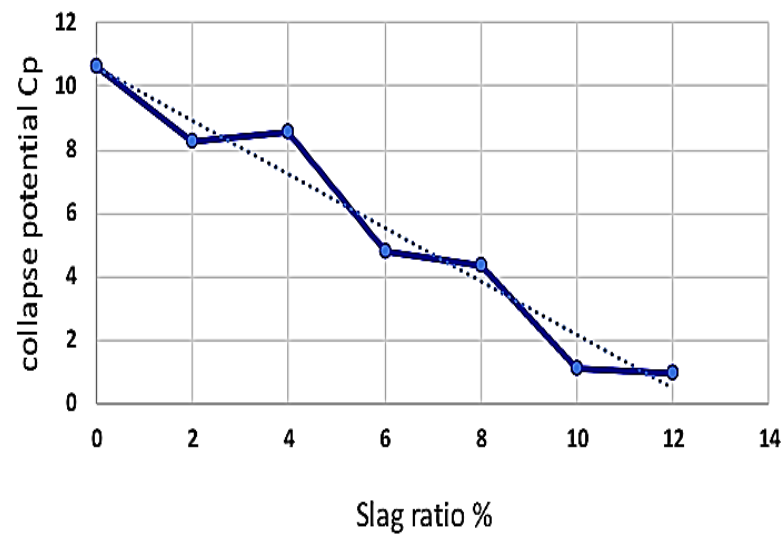

Fig. 11. Collapse potential $(\mathrm{Cp})-$ Slag ratio \% relation 


\section{CONCLUSION}

The effects of slag on the values of (c) and $(\varnothing)$ and collapse potential (Cp) are as follows:

- In dry case, the cohesion value (c) decreases as compared with its value without the additives. The loss in value of c equals (23.74) \% which happens when the slag ratio is $(10) \%$. It is the best slag ratio to improve the $(\varnothing)$ value

- In dry case, the highest internal friction angle $(\varnothing)$ is got when the slag ratio is equal to (10) \%.

- In wet case, the peak of increase in the cohesion (c) happens when the slag ratio is (10) \%

- In wet case, the angle of internal friction $(\varnothing)$ reaches its peak increase at the slag ratio (8) $\%$.

- The decrease in $(\mathrm{Cp})$ values continues with the increase of the slag percentage until the value of the potential collapse $(\mathrm{Cp})$ equals to $(0.95)$ when the slag ratio is equal to (12) \% and here the degree of improvement (ID) in the values of collapse potential reaches $(91.04) \%$.

- The optimum percentage of slag as an additive is (10) $\%$.

\section{REFERENCES}

[1] Muhauwiss FM. Physical Properties of Gypseous Soil after Gypsum Removal using EDTA Solution. Tikrit Journal of Engineering Sciences. 2018; 25 (2): 68 - 73

[2] Al-Busoda BS. Studies on the behavior of gypseous soil and its treatment during loading. M. Sc. Thesis, University of Baghdad, 1999.

[3] Al-Mufty AA. Effect of gypsum dissolution on the mechanical behavior of gypseous soils. Ph. D. Thesis, Civil Eng. Dep., University of Baghdad, Baghdad: University of Baghdad, 1997.

[4] Mahmood. Study of Gypsum Content of Soil at Selected Sites in Basrah Governorate South of Iraq for Engineering Purposes, Journal of Basrah Researches (Sciences). 2011; 37: 10-21.

[5] Fairbridge. The Encyclopedia of Geochemistry and Environmental Sciences. Pennsylvania. USA.: Dowden. Hutchinson D Ross. Inc., Stroudsburg, Pennsylvania, USA., 1972.

[6] Al-Obaidi AA, Al-Ashoishi QAA. Application of Dynamic Cone Penetration Test to Gypseous Soils. Tikrit Journal of Engineering Sciences 2018; 25 (4): 1-5.

[7] Taha MY, Al-Obaidi AA, and Taha OM. The use of Liquid Asphalt to Improve Engineering Properties of Gypseous Soils, Al-Rafidain Engineering Journal. 2006; 16(4): 13-29.

[8] Al-Obaidi AA. Mohammed SM Estimate of Bearing Capacity of Gypseous Soils from Field Data. Diyala Journal of Engineering Sciences. 2017; 10 (1): 1-20.
[9] Zedan AJ, Abbas HH, .Experimental Investigation of Square Footing Resting on Sand over Gypseous Soils. Tikrit Journal of Engineering Sciences 2020; 27 (1): 30- 39.

[10] Buringh P. Soils and Soil Conditions in Iraq, Ministry of Agriculture. 1960.

[11] Ibrahim AN. Schanz T. Gypseous Soil Improvement by Silicone Oil. Al-Nahrain Journal for Engineering Sciences. 2017; 20 (1): 49-58.

[12] Awn SH, Abbas HO. Improvement of Gypseous Soil by Compaction and Addition of Cement. Journal of Engineering and Sustainable Development. 2012; 16 (2): 74-88.

[13] Aziz MJ, H. Y. Gypseous Soil Improvement using Fuel Oil. International Journal of Civil and Environmental Engineering. 2011; 5 (3): 299-303.

[14] ASTM C989-99. Standard specification for ground granulated blast-furnace slag," doi: 10.1520/C0989-99 2003. [Online]. Available: http://www.astm.org.

[15] Bapat JD. Mineral Admixtures in Cement and Concrete. http://dl.merc.ac.ir/handle/Hannan/866: (C) 2013 by Taylor \& Francis Group, LLC, 2012.

[16] Al-Dafafea T. Influence of using the Local Slag on the Porosity and Absorption of the High Performance Concrete. Al-Taqani Journal. 2011; 24 (2): 42-56.

[17] ASTM D3080-98, Standard Test Method for Direct Shear Test of Soils Under Consolidated Drained Conditions, ASTM International, West Conshohocken, PA, 1998, www.astm.org, 1998.

[18] Fattah MY, Hameedi MK, Aswad MF. Determination of Collapse Potential of Gypseous Soil from Field and Laboratory Tests. Diyala Journal of Engineering Sciences. 2017; 10 (2): 75-85.

[19] ASTM D 5333-03.Standard test method for measurement of collapse potential of soils. Annual book of ASTM standards, 4, 2003.

[20] Jennings, Knight. The Prediction of Total Heave from the Double Oedometer Test. Transactions of the South African Institution of Civil Engineers. 1957; 7 (9):285-291.

[21] Fattah MY, Al-Musawi HH, Salman FA. Treatment of Collapsibility of Gypseous Soils by Dynamic Compaction. Kuala Lumpur, Malaysia: Geotechnical and Geological Engineering. 2012; 30 (6): 1369-1387.

[22] Abood M. The Treatment of Gypseous Soil with Sodium Silicate. Baghdad: MSc. Thesis University of Technology. Iraq. 1993.

[23] Ouatiki K, Bahi A, Ouadif L. Identification. Assessment and Improvement of Collapsible Soils: Case of Tufas Soils of CasablancaMorocco. ARPN Journal of Engineering and Applied Sciences. 2017; 12 (23): 6911-6919. 